\title{
Overweight between perception and reality
}

\author{
Cristian-Cosmin STRAVA ${ }^{1}$
}

\begin{abstract}
Introduction. Obesity is a disorder characterized by an amount of body fat over the normal limits. This could be reduced when there are no metabolic disorders with good alimentation and increasing the level of physical activity. In prevention of childhood obesity beside the institution on the field that has the obligation to promote a healthy lifestyle, parents have the main role. They are responsible for the food that their children get and also for their teaching for a healthy lifestyle. However, many times, the parents' attitude beside the obesity is inappropriate for various reasons. One of them is the fact that parents don't perceive correctly their children body weight.

The aim of this study is to assess the way a group of parents who have children enrolled to sports activity perceive their children body weight. We also wanted to check the way in which these perceptions are associated with possible attempts to lose weight. Participants and methods: In this study we evaluated 62 girls (average age: 10.29 \pm 1.32 years), these being enrolled to a private volleyball club from Timisoara. Testing protocol consisted in height measurement, evaluation of body composition and completing of a questionnaire by parents. Results. In the current research, there exist a few significant differences between the body mass index that was considered the base on which the children were put into different weight categories and the parent's perception on the body weight of their own children; $38.7 \%$ of the total of the children that were measured were overweight or obese and only $8.04 \%$ were involved in a program that helps weight loss. Conclusion. The vast majority of questioned parents underestimated the real body weight of their children, choosing an inferior weight category, inferior to the real one. These perception errors of the parents affect the level of concern regarding the body weight of the children and, thus, the optimal attitude concerning it.
\end{abstract}

Key words: overweight, perception, childhood obesity

\section{Rezumat}

Introducere. Obezitatea este o afecțiune caracterizată printr-o cantitate de grăsime corporală ce depășește valoarea normală. Aceasta poate fi redusă, atunci când nu există tulburări metabolice, printr-o alimentație corespunzătoare și creșterea nivelului de activitate fizică. În prevenția obezității infantile, pe lângă instituțiile din domeniu care au sarcina de a promova un stil de viată sănătos, rolul cel mai important îl au părintii. Acestia sunt direct responsabili pentru alimentația oferită copilului precum și de educarea lor privind un stil de viață sănătos. Cu toate acestea, de multe ori atitudinea părinților privind obezitatea este una inadecvată din diferite motive. Unul dintre acestea îl reprezintă faptul că părinții nu percep corect greutatea propriilor copii. Scopul acestui studiu este acela de a examina modul în care un grup de părinți care au copiii înscriși la o activitate sportivă, percep greutatea corporală a propriilor copii. În plus, ne-am dorit să verificăm și modul în care aceste percepții sunt asociate cu eventuale eforturi de a scădea în greutate. Participanți și

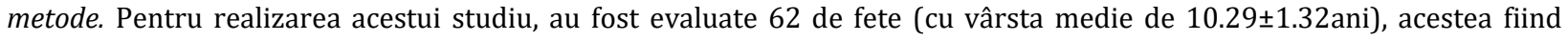
înscrise la un club de volei privat din Timișoara. Protocolul de testare a constat în măsurarea taliei, evaluarea compoziției corporale și completarea unui chestionar de către părinți. Rezultate. În cadrul cercetării de față, există diferențe semnificative între indicele de masă corporală, pe baza căruia copiii au fost încadrați în diferite categorii ponderale și percepția părinților asupra greutății corporale a propriilor copii; 38,7\% din totalul celor măsurați sunt supraponderali

${ }^{1}$ Assist. Professor, West University of Timișoara, Physical Education and Sport Faculty, PhD student at Babeș-Bolyai University of Cluj, Romania, e-mail: strava cosmin@yahoo.com 
sau obezi, doar 8,04\% dintre aceștia sunt implicati într-un program de scădere în greutate. Concluzii. Majoritatea părinţilor au subestimat greutatea reală a copiilor, alegând o categorie inferioară acesteia. Aceste erori de percepție ale părinților afectează nivelul de îngrijorare privind greutatea corporală a copiilor și, în consecință, și atitudinea optimă legată de aceasta.

Cuvinte cheie: exces ponderal, percepție, obezitate infantilă 


\section{Introduction}

Obesity is a disorder characterized by an amount of body fat over the normal limits. This could be reduced when there are no metabolic disorders with proper alimentation and increasing the level of physical activity [1].

The prevalence of obesity was rising in the last 3 decades becoming a global epidemic starting from tender ages [2-5]. These findings are very important and alarming because in so many cases childhood obesity represent a high risk for developing diseases as cardiovascular disease [6] and metabolic disorders [7].

In prevention of childhood obesity beside the institution on the field that has the obligation to promote a healthy lifestyle, parents have the main role. They are responsible for the food that their children get and also for their teaching for a healthy lifestyle [8]. Various studies highlight this fact and show us the fact that obesity combat programs had more success when in the program were included all the members of the family towards the programs were just the kids were included $[9,10]$.

However, many times, the parents' attitude beside the obesity is inappropriate for various reasons. One of them is the fact that parents don't perceive correctly their children body weight [11-19]. As a result of this wrong cognition about their own children weight and lack of education/information in this field, many of them don't ask for specialized help because they don't consider that their children weight is not in normal parameters.

There are studies that sustain the above idea through the fact that there is a positive relationship between a correct perception over the body weight and the degree of concern on it. From these studies it turns out that the subjects who were conscious that they have a body weight problem they were trying to lose weight or to keep it under control [20-23].
The purpose of this study is to examine the way a group of parents who have children enrolled to sports activity perceive their children body weight. We also wanted to check the way in which these perceptions are associated with efforts to lose weight.

\section{Participants and methods}

In this study we evaluated 62 girls (mean age: $10.29 \pm 1.32$ years), which were enrolled to a private volleyball club from Timișoara. Testing protocol consisted in height measurement and evaluation of body composition.

Body composition has been analyzed through multifrequency bioimpedance using InBody720 device, the subjects being informed not to eat or drink 3 hours before testing. From the obtained results we used body weight of the children, body mass index (BMI), skeletal muscle mass (SMM) and percentage of adipose tissue (PBF).

The second part of the test protocol consisted of the application of a questionnaire that was completed by the parents. The questionnaire was designed by us and it is consisting of 8 questions regarding the parents' perception about the body weight of their children, the degree of their concern on this parameter, the reasons for which their children participate in a physical activity program and if they registered them in a program to combat obesity where was the case.

Registered data were analyzed with GraphPad Prism 6 software.

\section{Results}

In table I are presented the results obtained by measuring anthropometric and some body composition parameters (height, weight, BMI, percentage of body fat). 
Table I. Results of anthropometric measurements and body composition parameters in the study group

\begin{tabular}{|c|c|c|c|c|c|c|c|}
\hline & Minimum & $\begin{array}{c}25 \% \\
\text { Percentile }\end{array}$ & Median & $\begin{array}{c}75 \% \\
\text { Percentile }\end{array}$ & Maximum & Mean & $\begin{array}{c}\text { Std. } \\
\text { Deviation }\end{array}$ \\
\hline Height (cm) & 120 & 140 & 149 & 153 & 167 & 145.7 & 11.03 \\
\hline Weight (kg) & 28.2 & 34.6 & 40.6 & 48.2 & 58.5 & 41.65 & 8.46 \\
\hline Body mass index $\left(\mathrm{kg} / \mathrm{m}^{2}\right)$ & 14.2 & 17.8 & 19.5 & 21.7 & 24.7 & 19.51 & 2.65 \\
\hline Percentage of Body Fat (\%) & 9.6 & 23.8 & 29 & 37.1 & 44.9 & 28.87 & 9.02 \\
\hline Skeletal muscle mass (kg) & 8.7 & 13.1 & 14.6 & 18.6 & 22.9 & 15.45 & 3.54 \\
\hline
\end{tabular}

As is presented in table I, the average height of the studied group is $145.7 \pm 11.03 \mathrm{~cm}$, with an average weight $41.65 \pm 8.46 \mathrm{~kg}$, a percentage of adipose tissue of $28.87 \%$ and a skeletal muscle mass of $15.45 \pm 3.54 \mathrm{~kg}$. Beside these data, the table also presents average body mass index of $19.51 \pm 2.65 \mathrm{~kg} / \mathrm{m}^{2}$.
Based on the body mass index calculated on each subject, they were shared in 4 weight categories: underweight, normal weight, overweight, obese. In table II it can be seen the distribution of the 4 categories mentioned above.

Table II. Classification of the subjects in 4 weight categories and parents' perception on their children weight

\begin{tabular}{l|c|c|c|}
\hline $\begin{array}{l}\text { Weight } \\
\text { category }\end{array}$ & $\begin{array}{c}\text { Real BMI } \\
\text { category }\end{array}$ & $\begin{array}{c}\text { Perceived } \\
\text { BMI category by } \\
\text { mother }\end{array}$ & $\begin{array}{c}\text { Perceived } \\
\text { BMI category by } \\
\text { father }\end{array}$ \\
\hline Underweight & $4(6.45 \%)$ & 0 & 0 \\
Healthy weight & $34(54.83 \%)$ & $46(74.19 \%)$ & $46(74.19 \%)$ \\
Overweight & $12(19.35 \%)$ & $14(22.58 \%)$ & $14(22.58 \%)$ \\
Obese & $12(19.35 \%)$ & $2(3.22 \%)$ & $2(3.22 \%)$ \\
\hline
\end{tabular}

Data gathered in this study shows that 24 children representing $38.7 \%$ of the total measured are overweighed or obese (table 2). Between the real weights category calculated on the basis of BMI and the perception of the parents on body weight of their kid is a significant difference $\left(x^{2}=13.1\right.$, $\mathrm{df}=3, \mathrm{p}=0.004$ ).

The level of parental concern about the weight of their children is low, as it can be seen in figure 1 obtaining a score of 2.51 on a scale from 1 to 7 , where 1 means unconcerned, 7 concerned.

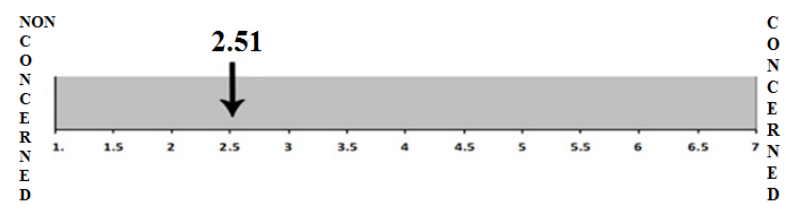

Figure1. Parents' concern about the body weight of their children
Although the level of concern is low, this still exists and it is observable when the BMI is higher than normal values After analyzing the two variables, there was observed a direct correlation between BMI and the level of concern $(r=0.75$, $\mathrm{p}=0.0001$ ).

In order to identify parents' level of concern, they were asked about the reasons their children were enrolled in a sports activity. In response, we received the following answers: socialization (58\%), health (23\%), fun (14\%) or others (5\%). In hindsight, out of all the participants within the research, only 5 of them take part in weight loss programs (nutritional counseling, physical training programs). This number is reached also because out of 12 cases of obesity, only 2 cases were correctly evaluated by the parents. 


\section{Discussions}

Body weight of the obese children was underestimated by their parents reaching a real percentage of $19.35 \%$ compared to $3.22 \%$ (perceived category), most of them being elected as overweight and not obese. The same tendency can be noted to some overweight people which were perceived as part of the category normal weight, thus increasing the real percentage of normal weight from $54.83 \%$ to $74.19 \%$.

These observations are also found in others studies [11-19] where the authors have found similar differences. In addition to what we observed, we find in Keller's study [7] who observes that in the family, fathers have a further perception about child's weight comparatively with mothers. Besides that, the study quoted above shows that older parents have a more erroneous perception about children's weight than younger parents.

Also, it was observed that the main reason for enrolling the children in a physical activity

\section{References}

1. Foreyt J., Goodrick G., GottoA. (1981). Limitations of behavioral treatment of obesity: Review and analysis, Journal Of Behavioral Medicine, 4(2), 159-174.

2. WHO. Obesity, Preventing and Managing the Global Epidemic (2000). Report of a WHO Consultation, WHO Technical Report Series 894.

3. Ebbeling C.B., Rawlak D.B., Ludwig D.S. (2002).Childhood obesity: public-health crisis, common sense cure, Lancet 360 : 473- 482

4. Lobstein T., Baur L., Uauy R. (2004).Obesity in children and young people: a crisis in public health, Obes Rev, 5(Suppl.1): 4-85.

5. Flynn M., McNeil D., Maloff B., Mutasingw, D., Wu M., Ford C., \& Tough S. (2006). Reducing obesity and related chronic disease risk in children and youth: a synthesis of evidence with 'best practice' recommendations, Obesity Reviews, 7(s1), 7-66.

6. Freedman D. S. (2002). Clustering of coronary heart disease risk factors among obese children, Journal of Pediatric Endocrinology and Metabolism, 15(8), 1099-1108.

7. Keller K., Olsen A., Kuilema L., Meyermann K., \& Belle C. (2013). Predictors of parental perceptions and concerns about child weight, Appetite, 62: 96-102.

8. Faith M. S., Van Horn L., Appel L. J., Burke L. E., Carson S. A., French H. A., et al. (2012). Evaluating parents and adult caregivers as "agents of change" for treating obese children. Evidence for parent behavior change strategies and research gaps, A scientific statement from the American Heart Association. Circulation, 125, 1186-1207. program was the socialization and not the one for health care; even $38.7 \%$ of children are obese and overweight; only $8.06 \%$ of them are involved in weight loss programs.

By comparing our results with those from literature, in our study we do not have differences in perceptions the gender or the age of the parents.

\section{Conclusions}

In the current research, there exist a few significant differences between the body mass index and the parent's perception on the body weight of their own children. The vast majority of them (overweight or obese) underestimated the ideal body weight, choosing an inferior weight category, opposite to the real one.

These perception errors of parents affect the level of concern regarding the body weight of their children and, thus, the optimal attitude concerning it.

9. Epstein L. H. (1996). Family-based behavioral intervention for obese children, International Journal of Obesity and Related Metabolic Disorders, 20(Suppl. 1), S14-S21.

10. Epstein L. H., Myers M. D., Raynor H. A., \&Saelens B. E. (1998). Treatment of pediatric obesity. Pediatrics, 101, 554;

11. Bayles B. (2010). Perceptions of Childhood Obesity on the Texas-Mexico Border, Public Health Nursing, 27(4), 320328.

12. Crawford P., Gosliner W., Anderson C., Strode P., BecerraJones Y., \&Samuels S. et al. (2004). Counselinglatina mothers of preschool children about weight issues: Suggestions for a new framework, Journal of The American Dietetic Association, 104(3), 387-394.

13. De La O A., Jordan K., Orti K., Moyer-Mileur L., Stoddard G., \&Friedrichs M. et al. (2009). Do Parents Accurately Perceive Their Child's Weight Status? Journal Of Pediatric Health Care, 23(4), 216-221.

14. Duncan D., Hansen A., Wang W., Yan F., \& Zhang J. (2015). Change in Misperception of Child's Body Weight among Parents of American Preschool Children, Childhood Obesity, 11(4), 384-393.

15. Figueroa V., Ip E. H., Gesell S. B., \&Barkin S. L. (2008). Accuracy of self- and parental perception of overweight among Latino preadolescents, North Carolina Medical Journal, 69, 88-91.

16. Glassman M., Figueroa M., \&Irigoyen M. (2011). Latino Parents' Perceptions of Their Ability to Prevent Obesity in Their Children, Family \& Community Health, 34(1), 4-16; 
17. Killion L., Hughes S. O., Wendt J. C., Pease D., \&Nicklas T. A. (2006). Minority mothers' perceptions of children's body size, International Journal of Pediatric Obesity, 1, 96-102.

18. Reifsnider E., Flores-Vela A., Beckman-Mendez D., Nguyen H., Keller C., \&Dowdall-Smith S. (2006). Perceptions of Children's Body Sizes Among Mothers Living on the TexasMexico Border (La Frontera), Public Health Nursing, 23(6), 488-495.

19. Ward C. (2008). Parental Perceptions of Childhood Overweight in the Mexican American Population: An Integrative Review, The Journal Of School Nursing, 24(6), 407-416.

20. Edwards N.M., Pettingell S., Borowsky I.W. (2010).Where perception meets reality: self-perception of weight in overweight adolescents, Pediatrics; 125: e452-e458.
21. Yost J., Krainovich-Miller B., Budin W., et al. (2010). Assessing weight perception accuracy to promote weight loss among U.S. female adolescents: a secondary analysis. BMC Public Health, 10: 465.

22. Ojala K., Vereecken C., Valimaa R., et al.(2007). Attempts to lose weight among overweight and non-overweight adolescents: a crossnational survey. Int J BehavNutrPhys Act.,4:50.

23. Chung A., Perrin E., \& Skinner A. (2013). Accuracy of Child and Adolescent Weight Perceptions and Their Relationships to Dieting and Exercise Behaviors: A NHANES Study, Academic Pediatrics, 13(4), 371-378. 